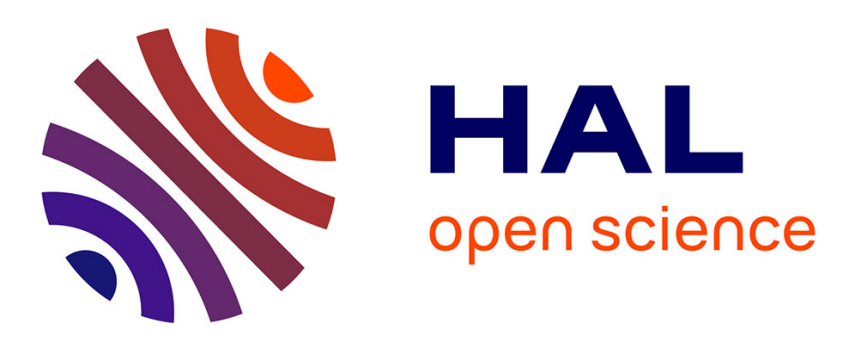

\title{
High pressure X-ray diffraction of cerium compounds in an improved diamond anvil cell
}

\author{
J.M. Leger
}

\section{To cite this version:}

J.M. Leger. High pressure X-ray diffraction of cerium compounds in an improved diamond anvil cell. Revue de Physique Appliquée, 1984, 19 (9), pp.815-817. 10.1051/rphysap:01984001909081500 . jpa-00245268

\section{HAL Id: jpa-00245268 https://hal.science/jpa-00245268}

Submitted on 1 Jan 1984

HAL is a multi-disciplinary open access archive for the deposit and dissemination of scientific research documents, whether they are published or not. The documents may come from teaching and research institutions in France or abroad, or from public or private research centers.
L'archive ouverte pluridisciplinaire HAL, est destinée au dépôt et à la diffusion de documents scientifiques de niveau recherche, publiés ou non, émanant des établissements d'enseignement et de recherche français ou étrangers, des laboratoires publics ou privés. 


\title{
High pressure X-ray diffraction of cerium compounds in an improved diamond anvil cell
}

\author{
J. M. Leger \\ E.R. 211, C.N.R.S., 1, place A. Briand, 92190 Meudon, France
}

\begin{abstract}
Résumé. - On a obtenu des diagrammes de poudre par diffraction $\mathrm{X}$ sur des échantillons soumis à de hautes pressions produites dans une cellule à enclumes de diamant. L'alignement des deux diamants est obtenu grâce à la libre rotation des deux axes portant le piston et le cylindre. On discute les premiers résultats obtenus jusqu'à $25 \mathrm{GPa}$ sur $\mathrm{CeB}_{6}$ et $\mathrm{CeTe}$. Le volume relatif de $\mathrm{CeB}_{6}$ diminue régulièrement avec la pression et on ne trouve pas de différence par rapport aux résultats rapportés sur $\mathrm{LaB}_{6}$. Le volume de $\mathrm{CeTe}$ varie de façon anormale avec la pression et présente une transition de phase $\mathrm{NaCl} \rightarrow \mathrm{CsCl}$.
\end{abstract}

\begin{abstract}
Powder X-ray diffraction patterns were recorded for samples submitted to high pressures in an improved diamond anvil cell where the alignment of the two diamonds is achieved by the free rotation of both axes bearing the piston and cylinder. First results on $\mathrm{CeB}_{6}$ and $\mathrm{CeTe}$ up to $25 \mathrm{GPa}$ are discussed. The relative volume of $\mathrm{CeB}_{6}$ decreases smoothly with pressure and no difference with previously reported results on $\mathrm{LaB}_{6}$ is noticed. The volume of $\mathrm{CeTe}$ shows an anomalous pressure dependence and a $\mathrm{NaCl} \rightarrow \mathrm{CsCl}$ phase transformation.
\end{abstract}

A diamond anvil cell has been designed for powder $\mathrm{X}$-ray diffraction under high pressures. This cell is based on the lever-arm system of the NBS type [1] and includes the long piston cylinder assembly of the cell by Mao and Bell [2] but has also additional new features.

Force is produced by compressing a spring by terms of a screw and the applied load is magnified by a factor of two on being transmitted to the diamonds via the lever arm system. The essential feature is that the piston which bears the lower diamond and the cylinder retaining the upper diamond are both linked to the lever arms by two axes which are able to rotate freely and smoothly. A constant and perfect alignment of the piston and cylinder axes is so provided whatever are the heights of the diamonds or the thickness of the gasket. The two rotation axes also avoid the need of sliding of the piston relatively to the thrust block and no seizing has ever been observed. Many causes of cracking the diamonds are thus eliminated and no need of lapping the piston to the cylinder has been encountered. In the same way the spring and the screw are also linked to the lever arms through two rotation axes which provide a very smooth variation of the applied load without any displacement of the application point of the force on the lever arms due to sliding. The classical hemi- sphere-plane geometry is used to secure centering and parallel alignment of the diamond faces $(\simeq 0.7 \mathrm{~mm})$. The diamond seats are made of tungsten carbide ; all the alignment screws are independent of the fixation ones. Routine work to $25 \mathrm{GPa}$ is now performed but no attempt for higher pressures has yet been made.

The incident $\mathrm{X}$-ray beam is produced by a molybdenum fine focus tube operated at $45 \mathrm{kV}$ and $9 \mathrm{~mA}$; $\mathrm{Zr}$ filtered radiation is used. A collimator made from two crossed slits $0.15 \mathrm{~mm}$ wide is located near the lower diamond. The 20 diffraction angle allowed is $40^{\circ}$. A centring device is used to move the whole diamond anvil cell so that only the sample is subjected to the X-ray beam; no diffraction line due to the gasket is observed in the X-ray pattern. The film technique has been used. The upper diamond table to film distance is mechanically kept constant ( $\simeq 23 \mathrm{~mm}$ ) and corrections for variations of the gasket thickness are applied. The recording film is flat and shrinkage is measured by use of a marker of known length in contact with the film. The patterns were analysed with a low magnifying microscope $(6 \mathrm{X}$ or $18 \mathrm{X}$ ). With this device, good diffraction patterns are obtained within 24 hours.

The studied compound is mixed with the pressure marker and the pressure transmitting medium and then 
placed into a $0.2 \mathrm{~mm}$ hole drilled in a X 750 Inconel fully hardened gasket. The pressure marker is $\mathrm{NaCl}$ or $\mathrm{CsCl}$. Silicon grease is used as the pressure transmitting medium for the following reasons :

- it is chemically inert with samples which are extremely moisture sensitive;

- it is soft at normal pressure, solidifies very rapidly (0.3-0.4 $\mathrm{GPa})$ but gives then only two strong diffraction lines ( $\sim 6.70$ and $3.56 \AA$ ) which progressively vanish; above $2.5 \mathrm{GPa}$ only the large $\mathrm{d}$ line remains which itself disappears completely around $6 \mathrm{GPa}$.

Early solidification does not introduce pertubatory effects in the pressure range of interest here in opposition to usual liquids which freeze in the 4-15 GPa range. In effect, using a solid pressure transmitting medium generates anisotropic stresses in the sample which lead to a larger apparent volume [3]. However at higher pressure these remain constant and their influence become weak and so the state equation of a solid has been here determined by following the procedure outlined by Kinsland [4].

The low pressure data (2-2.5 GPa with silicon grease) are discarded. A Birch or Murnagham state equation is then fitted to the data with the initial volume as a third unknown parameter, the two other ones being the bulk modulus and its first pressure derivative at normal pressure. This procedure is only necessary when the bulk modulus of the sample is markedly higher than the bulk moduli of the pressure marker and pressure transmitting medium. Otherwise no difference between the calculated and true values of the initial volume is observed.

\section{Results.}

1. $\mathrm{CeB}_{6}$. - The lanthanide hexaborides crystallize in the cubic structure with the $\mathrm{Pm} 3 \mathrm{~m}$ space group. The cell parameter of $\mathrm{CeB}_{6}$ is $4.146 \pm 0.005 \AA$ in normal conditions. Under pressure the following diffraction lines were observed : (100), (110), (111), (200), (211), (300), (310) and sometimes the (210), (220), (311) and (321) of lower intensities. The standard deviation for the cell parameter varies from 0.007 to $0.013 \AA$ and depends essentially on the time exposure. The pressure marker was $\mathrm{NaCl}$ in this case and the observed diffraction lines were as follows : (200), (220), (400) and (420). The observed deviation for the lattice constant of $\mathrm{NaCl}$ corresponds to a $0.3-0.4 \mathrm{GPa}$ deviation for pressures around $10 \mathrm{GPa}$, which is probably of the order of the pressure anisotropy.

The bulk modulus of $\mathrm{CeB}_{6}$ appears high and the above procedure has been used. A least square fit

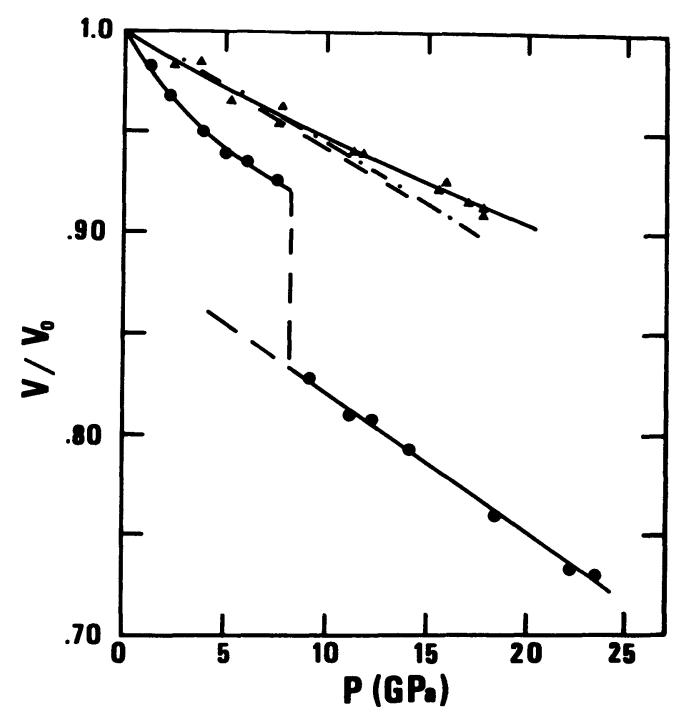

Fig. 1. - Relative volumes of $\mathrm{CeB}_{6}$ and $\mathrm{CeTe}$ as a function of pressure at room temperature. $\Delta \mathrm{CeB}_{6}$, present work, - $\mathrm{CeTe}$, present work, - —-_- $\mathrm{LaB}_{6}$ (the dashed lines show values calculated using the $B_{0}$ and $B_{0}^{\prime}$ from Ref. [5] and Ref. [6]).

to the data using the Murnagham state equation yields then $B_{0}=166 \mathrm{GPa}$ and $B_{0}^{\prime}=3.15$.

The uncertainties on this values are estimated to be about $5 \mathrm{GPa}$ and 0.5 respectively. The volume compression of $\mathrm{CeB}_{6}$ follows closely the results reported for $\mathrm{LaB}_{6}[5,6]$ but the values of the initial bulk modulus and first pressure derivative given above are more accurate because of the larger pressure range investigated and the better data fitting procedure used here.

2. CeTe. - The initial bulk modulus of CeTe is only $52.8 \pm 4 \mathrm{GPa}$ and the above procedure is no longer necessary; it increases very rapidly $\left(B_{0}^{\prime}=13.6 \pm 2\right)$. At $8 \mathrm{GPa}$ a first order $\mathrm{NaCl}-\mathrm{CsCl}$ crystallographic transition occurs. The structure of the high pressure phase has been ascertain by a run without any pressure marker. The volume change of $\mathrm{CeTe}$ with pressure has been interpreted [7] by a Kondo reentrant behaviour preferably to a back valence change by 0.3 at the transition. )

The X-ray technique used here (low power X-ray tube associated with a planar photographic detection) and the diamond anvil cell with its alignment device allow to obtain good quality $\mathrm{X}$-ray diffraction patterns in the laboratory within reasonable time ( $24 \mathrm{~h})$. Routine work to $25 \mathrm{GPa}$ is presently performed and considerable extent of the maximum working pressure should be obtained due to the improvements brought in the design of the diamond anvil cell. 


\section{References}

[1] Piermarini, G. J., J. Appl. Phys. 46 (1975) 2774.

[2] MaO, H. K., Bell, P. M. in Carnegie Institution of Washington Year Book (1977) 904.

[3] Singh, A. K., High Temp.-High Pressures 10 (1978) 641.

[4] Kinsland, G. L., High Temp.-High Pressures 10 (1978) 627 and 651.

[5] King. H. E. Jr, La Placa, S. J., Penney, T., Fisk, Z. in Valence Fluctuations in Solids, ed. Falicov,
L. M., Hanke, W., Maple, M. P. (North-Holland, Amsterdam) 1981, 333.

[6] Lundström, T., Lönnberg, B., Törma, B., Etourneau, J., Tarascon, J. M., Phys. Scripta 26 (1982) 414.

[7] Leger, J. M., Epain, R., Loriers, J., Ravot, D., Rossat-Mignod, J., Phys. Rev. B 28 (1983) 7125. 